\title{
Pentingnya Pelaku Industri Pariwisata Dibekali Uji Kompetensi Lewat Daring untuk Meningkatkan SDM Pariwisata di Indonesia
}

\author{
Nina Mistriani ${ }^{\mathrm{a}, 1, *}$, Aletta Dewi Maria ${ }^{\mathrm{b}, 2}$, Vera Damayanti $^{\mathrm{c}, 3}$ \\ ${ }^{a b}$ Sekolah Tinggi Ilmu Ekonomi Pariwisata Indonesia (STIEPARI), Semarang dan 50233, Indonesia \\ ${ }^{b}$ Universitas 17 Agustus 1945 (UNTAG), Semarang, dan 50133, Indonesia \\ ${ }^{1}$ ninamistriani.stiepari@gmail.com*; 2 aletta.dewimaria@gmail.com; ${ }^{3}$ veradamayanti1970@gmail.com \\ * corresponding author
}

Article history:

Submitted: May 20, 2020

Reviewed: June 8, 2020

Accepted: June 17, 2020

Published: June 30, 2020

Kata kunci: SDM Pariwisata, Industri Pariwisata, Kompetensi, Daring
Pentingnya Program Pemerintah membangun kebiasaan baik meningkatkan SDM berkualitas yang diterapkan diberbagai sektor, termasuk pariwisata. Presiden Joko Widodo dalam pidatonya menyatakan beberapa faktor menguatkan SDM yaitu sehat, cerdas, terampil dan sejahtera. Peranan Industri Pariwisata sekarang ini tidak bisa lagi dikesampingkan, karena peranannya dapat memberikan rekomendasi untuk meningkatkan kemampuan dan keahlian dibidang SDM Pariwisata. Penelitian ini bertujuan mengkaji pentingnya pelaku industri pariwisata dibekali daring dalam kegiatan uji kompetensi, sehingga terjadinya pemerataan dalam meningkatkan SDM Pariwisata di Indonesia baik pada SDM pendidikan maupun SDM yang bekerja pada industri pariwisata. Hal ini diperkuat dengan BNSP mengijinkan pelaksanaan asesmen/uji kompetensi jarak jauh dilakukan oleh LSP sesuai ketentuan Nomor: SE:011/BNSP/IV/2020 tanggal 03 April 2020. Penelitian ini menggunakan pendekatan kualitatif, yaitu pendekatan yang bersifat induktif. Jenis penelitian deskriptif dengan metode penelitian studi kasus. Hasil penelitian menunjukkan bahwa perencanaan, pengorganisasian, pengembangan, pengendalian pembiayaan uji kompetensi memerlukan daya dukung dari banyak stakesholder, sehingga prosesnya bisa berjalan dengan lancar. Keberhasilan peningkatan SDM sangat dipengaruhi oleh kondisi stabilitas keamanan dan politik, daya dukung SDM yang memiliki keahlian sesuai baik kualitas maupun kuantitasnya, adanya anggaran yang digunakan untuk mengembangkan sarana dan prasarana uji kompetensi pariwisata, kebijakan hukum yang memberikan kemudahan, keamanan, transparansi dan kenyamanan bagi pelaku industri pariwisata dalam proses pelaksanaan daring asesmen diberbagai daerah di Indonesia.

\begin{abstract}
The Importance of the Program The Government builds good habits to improve quality human resources that are applied in various sectors, including tourism. President Joko Widodo in his speech stated several factors that strengthen HR, namely healthy, smart, skilled and prosperous. The role of the tourism industry today is very important, because its role can provide recommendations to improve the capabilities and expertise in the field of tourism human resources. This study aims to analyze the importance of tourism industry players being guided online learning in competency tests, so that there is equity in improving Tourism Human Resources in
\end{abstract}


Keywords: Tourism HR, Tourism Industry, Competence, Online

Indonesia both in education and human resources working in the tourism industry. This is reinforced by BNSP allowing the implementation of remote competency assessment / testing carried out by LSP in accordance with Number: SE: 011 / BNSP / IV / 2020 dated April 3, 2020. This research uses a qualitative approach, which is an inductive approach. This type of descriptive research with case study research methods. The results showed that planning, organizing, developing, controlling the financing of competency tests require the carrying capacity of many stakeholders, so that the process can run smoothly. The success of increasing human resources is greatly influenced by the conditions of security and political stability, the carrying capacity of human resources who have expertise according to both quality and quantity, the budget used to develop facilities and infrastructure for tourism competency testing, legal policies that provide convenience, security, transparency and comfort for actors the tourism industry in the process of conducting online assessments in various regions in Indonesia.

Copyright (c) 2019 Politeknik Negeri Samarinda. All rights reserved.

\section{Pendahuluan}

Di Era Generasi milenial tidak bisa lepas dari yang namanya teknologi digital, baik itu untuk kehidupan sehari-hari maupun pada kegiatan bisnis. Oleh karena SDM Pariwisata harus memahami pentingnya persaingan dunia kerja setelah lulus dari dunia pendidikan. Era ini bukan hanya ijazah yang diminta, namun permintaan industri pariwisata semakin meningkat yaitu dengan siapnya SDM dibekali dengan kompetensi. Agar dapat berlomba-lomba diakui dalam bisnis serta mendapatkan kedudukan yang unggul pada persaingan ekonomi dunia pada sekarang ini. Sumber Daya Manusia (SDM) dituntut untuk mampu mendapatkan keterampilan dan keahlian yang terakreditasi secara hukum.

Pencari kerja diminta menyiapkan sertifikat kompetensi agar kompetitif menghadapi persaingan dunia kerja. Sebab, standar kompetensi sangat dibutuhkan perusahaan. Kriteria itu bahkan sudah diberlakukan sebagai syarat pencari kerja pada lowongan atau posisi tertentu. Mendasari hal itu, dunia pendidikan diminta membuat skema atau menyiapkan kurikulum sesuai dengan harapan industri pariwisata untuk dapat memenuhi kualifikasi yang dibutuhkan perusahaan.

Selain itu dalam pelaku industri pariwisata, uji kompetensi sangat dibutuhkan agar setiap karyawan memiliki standar kemampuan sesuai bidang masing2 dalam memberikan pelayanan bagi tamu hotel dan restoran. Selain itu sertifikat kompetensi sebagai bukti dasar tertulis kualitas profesionalitas seseorang dalam bekerja sesuai dengan kompetensinya.

Presiden Joko Widodo dalam pidato tentang nota Keuangan RAPBN Tahun 2020 menyatakan bahwa fokus RAPBN diarahkan kepada beberapa hal utama, yaitu pertama adalah menguatkan kualitas SDM yang sehat, cerdas, terampil dan sejahtera. Sedangkan pengamat pariwisata Chusmeru, 2019 mengatakan melalui antaranews.com. SDM pariwisata harus kompetitif dan tanggap terhadap perubahan tren wissata yang setiap saat berubah. Apalagi saat ini berasal dari generasi milenial yang cepat berubah perilaku wisatawannya. Pariwisata adalah industri jasa yang bertumpu pada pelayanan, sehingga kualitas dan kerjasama SDM sektor pariwisata memegang peranan penting, dan Indonesia membutuhkan SDM Pariwisata yang unggul agar siap berkompetisi dengan negara-negara lain yang sudah lebih maju pariwisatanya. Semua komponen pariwisata, mulai dari lembaga pendidikan kepariwisataan maupun industri pariwisata, seperti hotel, restoran, biro perjalanan wisata, pemandu wisata dan pengelola daya tarik wisata harus berfikir inovatif.

Pandemi covid-19 memberikan dampak langsung terhadap proses peningkatan sumberdaya manusia (SDM) Indonesia, baik pendidikan dan pelatihan tingkatan terendah 
sampai dengan yang tertinggi. Khusus peningkatan SDM kompetensi pariwisata di dunia pendidikan dimana uji kompetisi keahlian dari siswa SMK tahun 2020 tidak ada, sehingga tidak bisa menilai kompetensi keahlian sesuai kebutuhan industri pariwisata. Nilai kompetensi cukup dengan nilai semester pada tingkat kurikulum. Hal ini terjadi pula pada tingkat dunia pendidikan lainnya. Oleh karena itu pentingnya kerjasama dengan Lembaga Sertifikasi Profesi (LSP) untuk melakukan uji sertifikasi kompetensi kepada SDM Pariwisata dalam dunia pendidikan melalui daring yang sesuai dengan standar kompetensi industri pariwisata.

Adanya larangan untuk berkumpul dalam jumlah yang banyak, dan himbauan untuk melakukan social distancing dan physical distancing dalam rangka mencegah penyebaran virus corona, menyebabkan saat ini banyak dunia pendidikan tidak mengajukan kerjasama secara optimal untuk peningkatan bidang SDM ini melalui uji asesmen kompetensi sesuai kebutuhan industri pariwisata. Begitu juga dengan pelaku industri pariwisata yang banyak waktu luang di rumah/tempat bekerja dikarenakan kondisi pandemik, lebih baik dapat meningkatkan kompetensi, karena dengan media daring mempemudah pelaksanaan uji kompetensi.

Dengan kondisi pandemi ini, diharapkan muncul terobosan baru, dimana sekaligus menjadi lompatan perubahan besar pada setiap aktifitas LSP dalam peningkatan SDM Pariwisata yaitu dengan pelaku industri pariwisata ataupun dunia pendidikan dibekali uji kompetensi lewat daring.

Menurut Undang-undang Nomor 10 Tahun 2009 tentang Kepariwisataan, bahwa Pariwisata adalah berbagai macam kegiatan wisata dan didukung berbagai fasilitas serta layanan yang disediakan oleh masyarakat, pengusaha, Pemerintah, dan Pemerintah Daerah. Industri Pariwisata adalah kumpulan usaha pariwisata yang saling terkait dalam rangka menghasilkan barang dan/atau jasa bagi pemenuhan kebutuhan wisatawan dalam penyelenggaraan pariwisata. Kompetensi adalah seperangkat pengetahuan, keterampilan, dan perilaku yang harus dimiliki, dihayati, dan dikuasai oleh pekerja pariwisata untuk mengembangkan profesionalitas kerja. Sertifikasi adalah proses pemberian sertifikat kepada usaha dan pekerja pariwisata untuk mendukung peningkatan mutu produk pariwisata, pelayanan, dan pengelolaan kepariwisataan.

SDM merupakan salah satu faktor yang berperan penting dalam memajukan sektor pariwisata. Pentingnya SDM di sektor pariwisata adalah manusia (people) merupakan sumber daya yang sangat penting di sebagian besar organisasi. Khususnya di organisasi berbasis jasa (service-based organization), SDM berperan sebagai faktor kunci dalam mewujudkan keberhasilan kinerja (Evans, Campbell,\& Stonehouse, 2003). Pada beberapa industri, faktor manusia berperan penting dan menjadi faktor kunci sukses terhadap pencapaian kinerja. Seperti pada industri pariwisata, dimana perusahaan memiliki hubungan langsung yang bersifat intangible (tak berwujud) dengan konsumen yang sangat bergantung pada kemampuan individu karyawan dalam membangkitkan minat dan menciptakan kesenangan serta kenyaman kepada para konsumennya.

Pengembangan SDM di industri pariwisata saat ini memerlukan solusi yang ditempuh untuk dapat meningkatkan SDM pariwisata di Indonesia melalui peningkatan kualitas pendidikan dan pelatihan yang tepat, yang ditambahkan dengan kemampuan kompetensi sesuai bidangnya masing-masing. Dari uraian diatas keberadaan pelaku industri pariwisata perlu dibekali berbagai pelatihan, kerjasama, dan sosialisasi uji kompetensi lewat daring agar meningkatnya SDM Pariwisata diberbagai daerah mendapatkan kesempatan sama untuk meningkakan kompetensinya sesuai standar hukum. Peran penting keberadaan SDM di industri pariwisata, yaitu sebagai motor penggerak kelangsungan industri; pelaku utama yang menciptakan produk inti pariwisata (pengalaman) dan salah satu faktor penentu daya saing industri.

Tujuan yang ingin dicapai dari penelitian ini adalah :

1. Peran pelaku industri pariwisata yang harus memiliki sertifikat kompetensi melalui uji kompetensi untuk meningkatkan SDM Pariwisata 
2. Mengidentifikasi pelaksanaan asesmen/ uji kompetensi lewat jarak jauh (daring)

3. Fungsi manajemen sumber daya manusia untuk meningkatkan SDM pariwisata

Manajemen SDM Pariwisata penting untuk ditingkatkan dalam berbagai kondisi apapun. Sehingga sumber daya manusia harus dikembangkan dan dipelihara agar semua fungsi organisasi dapat berjalan seimbang. Kegiatan sumber daya manusia merupakan bagian proses manajemen sumber daya manusia yang paling sentral dan merupakan suatu rangkaian dalam mencapai tujuan organisasi/bisnis.

\section{Review Tinjauan Pustaka}

Industri pariwisata menururt Damanik, (2006) artinya semua usaha yang menghasilkan barang dan jasa bagi pariwisata yang dapat dikelompokkan ke dalam dua golongan yaitu: Pertama, pelaku langsung yang merupakan usaha-usaha wisata yang menawarkan jasa secara langsung kepada wisatawan atau yang jasanya langsung dibutuhkan oleh wisatawan. Kedua, pelaku tidak langsung yakni usaha yang mengkhususkan diri pada produkproduk yang secara tidak langsung mendukung pariwisata.

Menurut Moeheriono, (2009), pengertian dan arti kompetensi adalah karakteristik yang mendasari seseorang berkaitan dengan efektivitas kinerja individu dalam pekerjaannya atau karakteristik dasar individu yang memiliki hubungan kausal atau sebagai sebab-akibat dengan kriteria yang dijadikan acuan, efektif atau berkinerja prima atau superior di tempat kerja atau pada situasi tertentu.

Dale (2003), kompetensi berasal dari kata competence yang berarti kecakapan atau kemampuan. Terdapat beberapa pendapat tentang pengertian kompetensi. Kata sifat dari competence adalah competent yang berarti cakap, mampu, dan tangkas. Pengertian kompetensi ini pada prinsipnya sama dengan pengertian kompetensi menurut Stephen Robbin (2007), bahwa kompetensi adalah "kemampuan (ability) atau kapasitas seseorang untuk mengerjakan berbagai tugas dalam suatu pekerjaan, dimana kemampuan ini ditentukan oleh dua faktor yaitu kemampuan intelektual dan kemampuan fisik. Manfaat kompetensi untuk industri:

1. Identifikasi dan penyesuaian yang lebih baik atas keterampilan yang dibutuhkan industri

2. Akses yang lebih besar terhadap pendidikan dan pelatihan sektor publik yang relevan terhadap industri

3. Ditetapkannya dasar pemahaman yang umum dan jelas atas hasil pendidikan dan pelatihan industri melalui sertifikasi pencapaian kompetensi individu

4. Percaya diri yang lebih besar karena kebutuhan industri telah terpenuhi sebagai hasil penilaian berbasis standar

5. Ditetapkannya dasar sistem kualifikasi nasional yang relevan untuk industri

6. Efesiensi penyampaian yang lebih besar dan berkurangnya usaha pendidikan dan pelatihan ganda

7. Meningkatnya tanggung jawab dunia pendidikan dan penyedia pendidikan dan pelatihan ganda

8. Meningkatnya tanggung jawab dunia pendidikan dan penyedia dan pelatihan atas hasil pendidikan dan pelatihan

9. Mendorong pengembangan keterampilan yang luas dan relevam di masa depan.

Lembaga Uji Kompetensi dilakukan oleh badan lembaga independen dan berkompeten sesuai dengan jabatan yang diinginkan. Uji kompetensi oleh suatu badan ini tidak harus mengikuti pelatihan formal, penekanannya hanya pada kemampuan yang dimiliki dan disesuaikan dengan standar yang ditetapkan oleh suatu jabatan. Badan penguji kompetensi seperti Australia terdiri dari: Assesor, Advisor, Verifier, Atasan calon yang diuji, Mentor, Teman calon, Independen Assesor, Awarding body dan calon peserta uji.

Istilah Komunikasi Daring menurut Warschauer, M. (2001) mengacu pada membaca, menulis, dan berkomunikasi melalui / menggunakan jaringan komputer. Dengan kata lain, Komunikasi Daring adalah cara berkomunikasi di mana penyampaian dan penerimaan pesan dilakukan dengan atau melalui jaringan Internet. Komunikasi yang terjadi di dunia semu tersebut lazim disebut komunikasi di dunia maya atau cyberspace. Fungsi komunikasi dalam jaringan ialah 
berfungsi untuk menjalin hubungan dengan orang lain dalam jarak tertentu, antara lain :

1. Sebagai Informasi.

Komunikasi membantu proses penyampaian informasi yang diperlukan individu dan atau kelompok untuk mengambil keputusan dengan meneruskan data dan menilai pilihan-pilihan alternatif.

2. Sebagai Kendali.

Komunikasi bertindak untuk mengendalikan perilaku anggota dalam beberapa cara, setiap organisasi mempunyai wewenang dan garis panduan formal yang harus dipatuhi oleh karyawan.

3. Sebagai Motivasi

Komunikasi membantu perkembangan motivasi dengan menjelaskan para karyawan apa yang harus dilakukan bagaimana mereka bekerja baik dan apa yang dapat dikerjakan untuk memperbaiki kinerja jika itu di bawah standar.

4. Pengungkap Emosional.

Bagi sebagian komunitas, mereka memerlukan interaksi sosial, komunikasi yang terjadi di dalam komunitas itu merupakan cara anggota untuk menunjukkan kekecewaan dan rasa puas. Oleh karena itu, komunikasi menyiarkan ungkapan emosional dari perasaan dan sebagai alat untuk memenuhi kebutuhan sosial.

Komunikasi data seperti halnya orang yang saling berkomunikasi, yang melibatkan komponen : pesan, pengirim, media dan penerima.

Sertifikat BNSP ini nantinya dapat dimanfaatkan menjadi rekomendasi dan aktualitas bahwa yang bersangkutan memang memiliki kemampuan dan keahlian di bidangnya, yang kemudian juga sertifikasi profesi BNSP tersebut sah secara hukum dan bersifat nasional.

Sertifikasi profesi tidak hanya dapat digunakan untuk beberapa pekerjaan di suatu daerah saja, akan tetapi bisa dimanfaatkan untuk mencari kesempatan berkarier hingga ke mancanegara, karena sudah diakui juga oleh negara-negara lainnya.

Pelaksanaan asesmen/uji kompetensi jarak jauh dilakukan oleh LSP sesuai ketentuan yang tercantum dalam SE Nomor:
011/BNSP/IV/2020 tanggal 03 April 2020 melalui tahapan verifikasi dan persetujuan BNSP, oleh karena itu :

1. LSP tidak diperbolehkan menyebarkan informasi pelayanan dan pelaksanaan asesmen jarak jauh (daring) sebelum mendapatkan persetujuan asesmen jarak jauh/uji kompetensi jarak jauh oleh BNSP

2. Bagi LSP yang menyebarkan informasi pelayanan asesmen jarak jauh (daring/uji kompetensi jarak jauh) wajib menarik kembali dan membuat klarifikasi kepada BNSP dan publik.

Menurut Undang-undang Nomor 10 Tahun 2009 tentang Kepariwisataan, pengertian SDM dapat terkait dengan Pariwisata adalah "berbagai macam kegiatan wisata dan didukung berbagai fasilitas serta layanan yang disediakan oleh masyarakat, pengusaha, pemerintah, dan pemerintah daerah". Maka yang dimaksud dengan SDM Pariwisata adalah Seluruh aspek manusia yang mendukung kegiatan wisata baik bersifat tangible maupun intangible yang bertujuan untuk memenuhi kebutuhan dan mewujudkan terciptanya kepuasan wisatawan serta berdampak positif terhadap ekonomi, kesejahteraan, dan kelestarian lingkungan dan budaya di suatu kawasan wisata.

SDM merupakan salah satu faktor yang berperan penting dalam memajukan sektor pariwisata. Pentingnya SDM di sektor pariwisata adalah manusia (people) merupakan sumber daya yang sangat penting di sebagian besar organisasi.

Pada beberapa industri, faktor manusia berperan penting dan menjadi faktor kunci sukses terhadap pencapaian kinerja. Seperti pada industri pariwisata, dimana perusahaan memiliki hubungan langsung yang bersifat intangible (tak berwujud) dengan konsumen yang sangat bergantung pada kemampuan individu karyawan dalam membangkitkan minat dan menciptakan kesenangan serta kenyaman kepada para konsumennya. Peran penting keberadaan SDM di industri pariwisata, yaitu sebagai motor penggerak kelangsungan industri; pelaku utama yang menciptakan produk inti pariwisata (pengalaman); dan salah satu faktor penentu daya saing industri. 
Fungsi Manajemen Sumber Daya Manusia Menurut Hasibuan (2013) menyebutkan bahwa fungsi manajemen sumber daya manusia meliputi perencanaan, pengorganisasian, pengarahan, pengendalian, pengadaan, pengembangan, kompensasi, pengintegrasian, pemeliharaan, kedisiplinan, dan pemberhentian.

\section{Metodologi Penelitian}

Penelitian ini menggunakan metode kualitatif. Menurut Sugiyono (2011), metode kualitatif dapat berfungsi untuk menggambarkan dan memahami makna di balik data-data yang tampak. Menurut Sugiyono (2011), metode kualitatif akan cenderung mengarahkan penelitian pada jenis penelitian deskriptif. Oleh sebab itu, penelitian ini merupakan sebuah jenis penelitian kualitatif deskriptif.

Metode pengumpulan data yang digunakan dalam penelitian ini adalah melalui : wawancara yakni melakukan tanya jawab secara langsung dengan Pelaku Industri Pariwisata dari berbagai bidang yaitu perhotelan, biro perjalanan wisata, jasa boga, spa, pemandu wisata dll, serta akademisi yaitu mahasiswa STIEPARI Semarang Program Studi Manajemen Perhotelan dan Pariwisata, UNTAG Semarang Fakultas Bahasa \& Budaya (FBB), telaah dokumen atau studi pustaka, yakni mengumpulkan data-data yang bersumber dari literature, buku, dan bahan lainnya yang ada relevansinya dengan penelitian ini.

Tujuan penelitian ini mengkaji peran pelaku industri meningkatkan SDM Pariwisata, mengidentifikasi LSP bagaimana jika melaksankan asesmen/uji kompetensi kepada pelaku industri pariwisata dan dunia akademisi melalui asesmen/uji kompetensi jarak jauh (daring), Bagaimana fungsi manajemen sumber daya manusia untuk meningkatkan SDM pariwisata di Indonesia

Assessment yang biasanya secara langsung ke lapangan, namun dalam masa pandemik covid-19 tidak bisa terlaksana, padahal ini penting. Selain itu adanya peraturan BNSP yang melaksankan asesmen/uji kompetensi jarak jauh yang sosialisasi ini belum banyak LSP memahami prosedurnya, ataupun belum mengetahuinya sasaran segmen pasar dalam masa pandemik apakah membutuhkan ataukah harus berhenti dahulu. Oleh karena itu pentingnya fungsi manajemen SDM yang dilakukan oleh LSP dan stakeholder dalam hal ini, sehingga proses perencanaan, pengembangan, organisasi, pengendalian uji kompetensi dapat berjalan dengan baik.

\section{Hasil dan Diskusi}

1. Peran pelaku industri pariwisata yang harus memiliki sertifikat kompetensi melalui uji kompetensi untuk meningkatkan SDM Pariwisata

Sumber Daya Manusia (SDM) memiliki peranan penting dalam pengembangan pariwisata untuk mendukung percepatan dan perluasan pembangunan ekonomi Indonesia. Lemahnya kualitas SDM Pariwisata pada masa pandemic covid-19 dimana pelaku industri pariwisata banyak yang dirumahkan untuk sementara, namun pada masanya new normal tetap harus bekerja kembali sesuai dengan protokol kesehatan yang telah ditetapkan oleh pihak pemerintah. Oleh karena itu sangat penting uji kompetensi tetap dapat dilaksankan oleh pihak lembaga sertifikasi. Uji Kompetensi sangat dibutuhkan agar setiap karyawan memiliki standar kemampuan sesuai kompetensinya masing-masing, sehingga dapat memberikan pelayanan bagi tamu dengan baik dan benar.

Ada beberapa yang berfikir, jika belum memiliki sertifikat kompetens di pandang belum kompeten/belum dapat bekerja secara profesional. Sertifikat kompetensi diibaratkan seperti SIM dalam bekerja. Dengan adanya sertifikat kompetensi kita lebih di percaya kemampuan kita. Adanya Sertifikat kompetensi berarti seseorang telah menempuh pembelajaran, pelatihan, maupun pengalaman kerja sesuai standar hukum. Bahkan dalam dunia pendidikan jika belum memiliki sertifikat kompetensi, maka dalam mencari pekerjaan akan kesulitan. Sertifikat kompetensi diperlukan untuk menunjang karir. Bahkan sertifikasi dapat dijadikan pertimbangan dalam mendapatkan standar gaji mencapai kesejahteraan tenaga kerja, karena diakui secara professional.

2. Mengidentifikasi Pelaksanaan asesmen/ uji kompetensi lewat jarak jauh (daring)

a. Asesmen/Uji kompetensi

1) Prosedur Uji Kompetensi 
Pada prosedur uji kompetensi LSP Pariwisata menjadi tiga tahapan yaitu proses awal assesmen mandiri, proses pra asesmen (test tertulis), dan proses asesmen (uji kompetensi) dengan praktek demo dan wawancara.

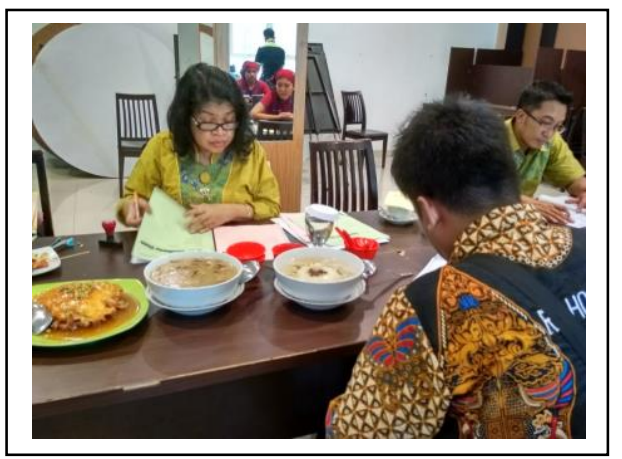

Sumber : Dokumentasi Penulis Uji Kompetensi Cook (Aletta Dewi Maria Th)

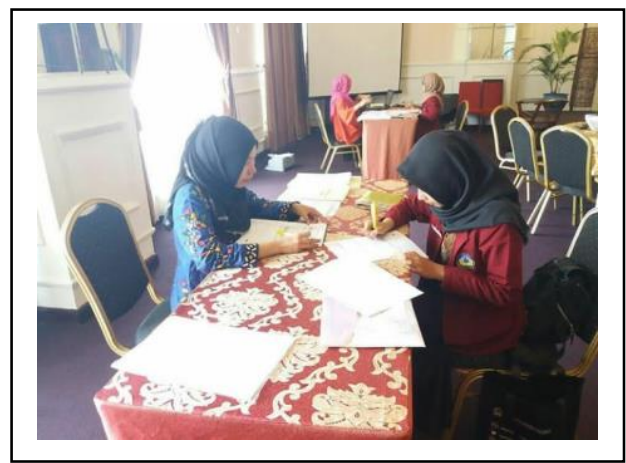

Sumber : Dokumentasi Penulis

Uji Kompetensi Tour Planner (Nina Mistriani)

2) Kualitas Lulusan

LSP Gunadharma yang sudah dikenal di Indonesia, bahkan di Jawa Tengah adalah salah satu LSP yang dipercaya oleh pemerintaan untuk mencetak SDM Pariwisata. LSP ini juga telah menghasilkan kualitas lulusan di berbagai kota di Indonesia, namun hambatan yang terjadi biasanya, dimana penguji saat bersamaan tidak bisa ke luar kota, dikarenakan ada event kerja yang tidak bisa ditinggalkan. Hal ini tetap oleh LSP Gunadharma menjembatani pelayanan yang baik, sehingga jumlah Assesor yang cukup banyak tetap dapat memberikan kualiatas pelayanan yang baik. Pelaksanaan Uji Kompetensi tetap berjalan dengan baik.
Hasil lulusan yang bekerja secara professional berhasil dinyatakan kompeten secara professional di berbagai penjuru di Indonesia dengan bidang seperti memasak, Pramusaji, Biro Perjalanan Wisata, dan lainnya.

b. Uji kompetensi pada lembaga sertifikasi profesi bidang pariwisata

1) Kelembagaan

Identifikasi dilaksanakan terhadap LSP Pariwisata Gunadarma Utama dengan alamat Griya Tata Utama Kav. 3A-4A, Pesantren, Mijen, Semarang City, Central Java 50212. Ketua Lembaga Sertifikasi Profesi (LSP) Gunadarma Vera Damayanti S.E., S.Pd., M.Pd. Uji Sertifikasi bidang: Perhotelan, Biro Perjalanan Wisata, Pemandu Wisata, Spa, Jasa Boga/Cook, Pemandu Karaoke, Arung Jeram, Ekowisata, dll.

Sesuai dengan aturan BNSP, struktur organisasi LSP minimal terdiri dari dua unsur yaitu unsur pengarah dan unsur pelaksana. Pengarah terdiri dari ketua yang merangkap anggota dan anggota berasal dari asosiasi profesi atau asosiasi industri. Unsur pelaksana terdiri dari ketua, bagian administrasi, bidang standardisasi, dan bidang manajemen mutu. Ketiga lembaga tersebut memenuhi syarat minimal pengurus yang ditetapkan oleh BNSP.

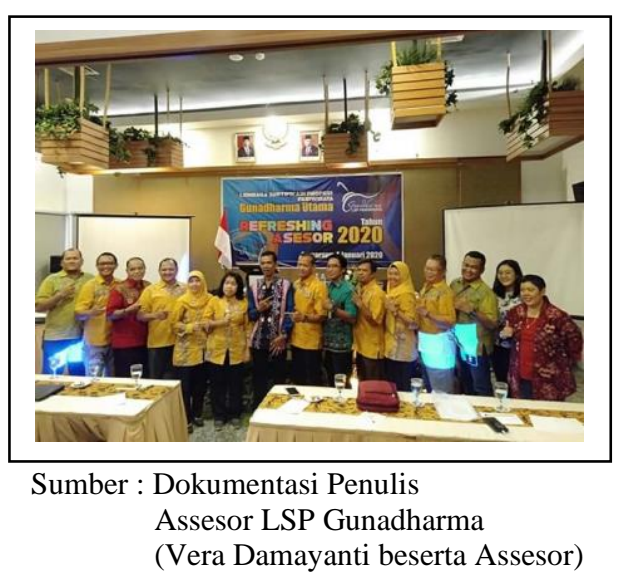

2) Dasar Hukum Pendirian BNSP dan LSP

a) Undang-Undang N0. 13 Tahun 2003 tentang Ketenagakerjaan, pasal 18.

b) Undang-Undang No. 20 Tahun 2003 tentang Sistem Pendidikan Nasional, pasal 61.

c) Undang-Undang No. 5 Tahun 1984 tentang Perindustrian (Lembaran Negara tahun 1984 No. 22, Tambahan Lembaran Negara Nomor 3274). 
d) Peraturan Pemerintah No. 52 Tahun 2012 tentang Sertifikasi Kompetensi dan Sertifikasi Usaha di bidang Pariwisata.

e) Peraturan Pemerintah No. 31 Tahun 2006 tentang Sistem Latihan Kerja Nasional.

f) Peraturan Pemerintah No. 23 Tahun 2004 tentang Badan Nasional Sertifikasi Profesi (BNSP).

g) PerMenakertrans PER.22/MEN/IX/2009

No. Penyelenggaraan Pemagangan Dalam Negeri.

h) PerMenakertrans No. PER. 21/MEN/X/2007 tentang Tata Cara Penetapan Standar Kompetensi Kerja Nasional Indonesia.

i) PerMenakertrans No. PER17/MEN/VI/2007 tentang Tatacara Perizinan dan Pendaftaran Lembaga Pelatihan Kerja.

j) Surat Keputusan Menteri Tenaga Kerja dan Transmigrasi Republik Indonesia No. KEP-96A/MEN/VI/2004 tentang Pedoman Penyiapan dan Akreditasi Lembaga Sertifikasi Profesi

3) Sumber Daya Manusia LSP

Tenaga Penguji LSP Pariwisata Gunadharma Utama memiliki penguji dengan jumlah sekitar 200 orang dari berbagai profesi sesuai kompetensinya. Asesor dari pelaku industri dengan berbagai keahlian dibidangnya seperti $F O$, $H K$, service, cook, pastry, tour planner, ticketing, dll. Assesor juga bahkan untuk meningkatkan kompetensinya selalu upgrade ilmu pengetahuannya melalui pelatihan, magang dll. Selain itu assessor wajib dibekali dengan sertifikat kompetensi dibidangnya.

Bagi Akademisi yang menjadi assessor harus dibekali selain sertifikat kompetensi tentunya harus mengikuti assosiasi, contoh menjadi anggota EHK untuk HK, ICA untuk Cook, BPD PHRI untuk Perhotelan, HPI untuk Guide, AELI untuk Arung Jeram, ASITA untuk Biro Perjalanan Wisata, dll.

4) Sarana dan Prasarana Uji Kompetensi Sarana Prasarana dalam uji kompetensi biasanya di hotel, lokasi TUK yang ditentukan sesuai standar yang ditetapkan.

5) Pembiayaan Uji Kompetensi
Biaya Uji Kompetensi biasanya mendapatkan bantuan dari Pemerintah, ini sangat meringankan peserta uji kompetensi dan semakin banyak minat peserta untuk uji kompetensi, maka semakin banyak pula SDM Pariwisata yang kompeten dibidangnya, namun terkadang jika tidak adanya bantuan dari pemerintah, maka biasanya dengan menggunakan dana mandiri. Jika dengan membayar biaya mandiri yaitu sekitar Rp. $600.000,-$, sehingga jika ada subsidi hanya cukup dengan membayar Rp. 300.000,-.

\section{c. Asesmen/uji kompetensi lewat jarak jauh (daring)}

BNSP mengijinkan pelaksanaan asesmen/uji kompetensi jarak jauh dilakukan oleh LSP sesuai ketentuan Nomor: SE:011/BNSP/IV/2020 tanggal 03 April 2020. Sedangkan berdasarkan Surat Edaran Nomor: SE.011/IV/2020 tentang upaya memutus rantai penyebaran Covid 19 dalam pelaksanaan pelayanan pada badan nasional Sertifikasi Profesi. Pelaksanaan Asesmen/Uji Kompetensi oleh LSP:

1) Pelayanan Asesmen/Uji Kompetensi oleh LSP dilakukan secara terbatas dan menjalankan prinsip pembatasan sosial dan kebijakan pusat dan daerah dalam penanganan covid 19

2) Pelaksanaan Asesmen/Uji Kompetensi Jarak Jauh dengan memanfaatkan teknologi informasi dibolehkan dengan ketentuan:

a) LSP menjamin teknologi/sistem yang digunakan dapat telusur terhadap bukti kompetensi yang dimiliki oleh asesi, terjamin kerasahasiaan, keamanan dan prinsip asesmen serta aturan bukti yang telah ditetapkan sesuai dengan pedoman asesmen sebagai penjaminan mutu sertifikasi kompetensi.

b) LSP menetapkan persyaratan teknis TUK Asesmen/Uji Kompetensi Jarak Jauh dan menjamin persyaratan teknis skema sertifikasi tersebut tersedia dan dapat digunakan.

c) LSP mengajukan permohonan Asesmen/Uji Kompetensi Jarak Jauh BNSP dengan melampirka SOP Asesmen/Uji Kompetensi Jarak Jauh dan penjelasan teknologi informasi atau sistem/aplikasi yang digunakan. 
d) LSP menjamin pelaksanaan Asesmen/Uji Kompetensi Jarak Jauh dengan tetap menjalankan prinsip pembatasan sosial dan sesuai kebijakan pemerintah pusat dan daerah dalam penanganan covid 19

3) Permohonan persetujuan Asesmen/Uji Kompetensi Jarak Jauh tersebut (poin 2c) akan diverifikasi BNSP dan surat persetujuan Asesmen/Uji Kompetensi Jarak Jauh akan diterbitkan paling lambat 7 hari kerja setelah dokumen persyaratan dinyatakan lengkap dan sesuai dengan prinsip-prinsip diatas.

Berdasarkan aturan diatas, maka BNSP dan Pemerintah mendukung program uji kompetensi dilaksanakan dalam via daring. LSP yang bertugas mencetak calon pelaku industri pariwisata dalam hal ini harus difasilitasi sosialisasi dan pelatihan daring assessment yang sesuai dengan harapan sesuai standar kompetensi yang ditetapkan secara hukum.

\section{Fungsi manajemen sumber daya manusia untuk meningkatkan SDM pariwisata}

Manajemen Sumber Daya Manusia (MSDM) merupakan suatu bidang manajemen khusus mempelajari hubungan dan peranan manusia dalam organisasi/perusahaan. Pada masalah yang khusus berhubungan dengan tenaga kerja manusia saja. Manusia selalu berperan aktif dan dominan dalam setiap kegiatan organisasi karena manusia menjadi perencana, pelaku, dan penentu terwujudnya tujuan yang ingin dicapai. Fungsi manajemen sumber daya manusia meliputi perencanaan, pengorganisasian, pengendalian, pengembangan, pengarahan, pengadaan, kompensasi, pengintegrasian, pemeliharaan, kedisiplinan, dan pemberhentian.

$\begin{array}{cccc}\text { Perencanaan } & \text { merupakan fungsi } \\ \text { pertama dan } & \text { utama } & \text { dalam }\end{array}$ organisasi/perusahaan. Perencanaan SDM menurut Siagian dalam Sugiyono (2015) adalah langkah-langkah tertentu yang diambil oleh manajemen guna menjamin bahwa bagi organisasi tersedia tenaga kerja yang tepat pada waktu yang tepat. Kesemuanya itu dalam rangka mencapai tujuan dan berbagai sasaran yang telah dan akan ditetapkan. perencanaan termasuk kedalam pembiayaan dan perkiraan SDM akan berpengaruh dan dipengaruhi oleh rencana jangka panjang perusahaan.

BNSP sangat ketat dalam menjaga mutu dan kualitas asesmen. Sekitar 1 bulan sampai akhirnya BNSP menurunkan SK Lisensi Pelaksanaan Uji Kompetensi secara Daring/Online Nomor KEP. 0832/BNSP/IV/2020 tanggal 22 April 2020. Ini bisa jadi sejarah bagi LSP pertama yang selalu siap menghadapi segala situasi dan kondisi. LSP tersebut adalah Lembaga Sertifikasi Profesi Majelis Ulama Indonesia (LSP MUI). Nur Wahid yang merupakan Direktur LSP MUI Bidang Penjaminan Produk Halal, bahwa LSP melakukan antisipasi secara cepat dalam kondisi pandemi Covid-19. Antisipasi ini dilakukan dengan mengajukan permohonan kepada Badan Nasional Sertifikasi Profesi (BNSP) untuk dapat melakukan uji kompetensi secara daring.

Berdasarkan pernyataan diatas, maka perlunya perencanaan apabila LSP akan melakukan uji kompetensi melalui daring, tentunya atas kesepakatan bersama. Assesor, Asesi dan LSP tentunya harus sudah siap dengan sosialisasi dan pelatihan daring. Oleh karena itu pengorganisasian dibutuhkan untuk mendukung perencanaan pelaksanaan daring.

Pada dasarnya pengorganisasian merupakan proses penyusunan struktur organisasi yang sesuai dengan sasaran, sumber daya yang dimiliki, dan lingkungan yang melingkapinya. Pengorganisasian sebagai salah satu fungsi manajemen merupakan sistem kerjasama beberapa orang yang dilaksanakan dengan pembidangan dan pembagian seluruh pekerjaan atau tugas, dengan membentuk sejumlah satuan kerja yang menghimpun pekerjaan dalam satu unit kerja menurut Supriyatna dalam Arumsari (2017).

Pengorganisasian di LSP sudah terstruktur dengan baik, tinggal kita melaksanakan fungsinya disesuaikan dengan peraturan yang ada di BNSP. Pengorganisasian dapat dilakukan di LSP dengan pemberian tugas pada masing unsur pengarah dan unsur pelaksana.

Pengendalian untuk memastikan bahwa kegiatan dalam organisasi dilakukan sesuai dengan yang direncanakan. Fungsi Pengendalian atau controlling ini juga memastikan sumber-sumber daya organisasi 
telah digunakan secara efisien dan efektif untuk mencapai tujuan organisasinya. Memastikan standar uji kompetensi yang dilakukan secara offline tetap dapat diterapkan secara online dan bisa diverifikasi. Hal ini tentunya dituangkan dalam prosedur rinci dan standard operating procedure (SOP) pelaksanaan uji kompetensi online. Hal ini tergantung dari kesiapan LSP dalam melaksanakan uji kompetensi secara online dilihat dari aspek perangkat, sistem, maupun pelaksanaan SOP. Agar hasil memuaskan dan sesuai dengan standar dari BNSP yang terstandar hukum, maka prosedur rinci assessment daring sebaiknya diadakan pelatihan assessment terlebih dahulu. Sehingga LSP dapat melakukan langkah yang tepat dalam menantisipasi kemungkinan kesalahan, kecurangan ataupun kemungkinan eror yang dapat teradi di uji kompetensi (TUK) atau selama proses asesmen berlangsung.

Pengembangan menjadi manfaat yang sangat besar bagi pelaku industri pariwisata untuk dapat bekerja lebih baik dan berkualitas. Pengembangan ini penting untuk mengenali segala potensi dalam dirinya sendiri. Sertifikat Uji kompetensi diperlukan untuk menunjang karir, dan sertifikat uji kompetensi besar harapan calon pekerja pariwisata di dunia industri pariwisata untuk dapat dinyatakan layak/kompeten sesuai dengan kompetensinya dan mendapatkan penghargaan oleh pelaku industri pariwisata, selain itu bagi pelaku industri sertifikat sebagai meningkatkan potensi kompetensi dalam professional kerja.

Pengendalian dan pengembangan pembiayaan uji kompetensi memerlukan daya dukung dari banyak stakesholder, sehingga prosesnya bisa berjalan dengan lancar. Peran yang dimaksud adalah adanya bantuan anggaran dari pemerintah kembali untuk peningkatan SDM Pariwisata.

Keberhasilan peningkatan SDM sangat dipengaruhi oleh kondisi stabilitas keamanan dan politik. Dalam kondisi pandemic seperti ini tentunya ini salah satu jalan terbaik untuk meningkatkan dasar SDM Pariwisata. Jika new normal dalam pengembangan SDM Pariwisata harus berlangsung secara langsung, tetap harus melakukan prosedur protokol yang baik dan benar, namun pada kenyataannya untuk dapat menjangkau pemerataan SDM Pariwisata, uji kompetensi via daring menjadi alternatif mengikuti perkembangan industri 4.0 menuju digitalisasi. Salah satu upaya dengan menggunakan media via daring adalah mengharuskan peserta asesmen menggunakan dua kamera pada aplikasi online meeting room (Zoom), yakni menghadap dan membelakangi peserta. Dengan begitu, TUK dapat terlihat secara 360 derajat dan asesor dapat memastikan bahwa ruangan memenuhi persyaratan TUK. Tentunya perlu didukung sesuai dengan daya dukung SDM yang memiliki keahlian sesuai baik kualitas maupun kuantitasnya, serta kebijakan hukum yang memberikan kemudahan, keamanan, transparansi dan kenyamanan bagi pelaku industri pariwisata dalam proses pelaksanaan daring asesmen diberbagai daerah di Indonesia.

\section{Kesimpulan}

Berdasarkan keseluruhan uraian yang telah dikemukakan dapat disimpulkan bahwa pentingnya pelaku industri pariwisata dibekali daring dalam kegiatan uji kompetensi, sehingga terjadinya pemerataan dalam meningkatkan SDM Pariwisata di Indonesia baik pada SDM pendidikan maupun SDM yang bekerja pada industri pariwisata. Dalam kegiatan tersebut dibutuhkan perencanaan, pengorganisasian, pengembangan, pengendalian dan daya dukung dari banyak stakesholder, sehingga prosesnya bisa berjalan dengan lancar. Keberhasilan peningkatan SDM memiliki SDM yang keahliannya sesuai baik kualitas maupun kuantitas dengan bidang kompetensinya. Adanya bantuan anggaran yang digunakan untuk mengembangkan uji kompetensi pariwisata, dan kebijakan hukum dapat memberikan kemudahan, keamanan, transparansi dan kenyamanan bagi pelaku industri pariwisata dalam proses pelaksanaan daring asesmen diberbagai daerah di Indonesia.

\section{References}

Lembaga Sertifikasi MUI Gelar Uji Kompetensi Daring Pertama. 2020. https://mui.or.id

Masuk Dunia Kerja Butuh Standar Kompetensi. Suaramerdeka.com. 2019 
[3] Andhika Kharismawan, Dwi Ratna Hidayati. 2016. Implementasi Manajemen Sumber Daya Manusia Sebagai Pendukung Pengembangan Bisnis CV. Kajeye Food. Jurnal Pamator. 9. 2: 66-71. (Artikel in Journal)

[4] Besterfield, Dale H. et al. 2003. Total Quality Management. Pearson Education, Inc. New Jersey.

[5] Damanik, Janianton, Helmut F. Weber. 2006. Perencanaan Ekowisata. Yogyakarta: Andi Offset.

[6] Hanung Eka Atmaja, Shinta Ratnawati. 2018. Pentingnya Manajemen Sumber Daya Manusia Untuk Meningkatkan Usaha Kecil Menengah. Jurnal Rekomen. 2. 1:2134. (Artikel in Journal)

[7] Irwan Yudimahasiswa Iain Samarinda. Kompasiana.com. Perkembangan Era Digital yang Sangat Pesat. 2019.

[8] M Razi Rahman. Pentingnya mengangkat daya saing SDM sektor pariwisata. https://www.antaranews.com. 2019.

[9] M. Hari Atmoko. Kemendikbud siapkan alternatif pengganti UKK karena pandemi COVID-19. https://www.antaranews.com. 2020.

[10] Makmur, Arga. 2018. Makalah Simulasi Digital (Simdig) Tentang Komunikasi Dalam Jaringan (Daring). https://pastimenet.blogspot.com.

[11] Melati Indri Hapsari. 2017. Pengkajian Program Kursus Bidang Pariwisata. Jurnal Ilmiah VISI PGTK PAUD Dan DIKMA. 12. 1: 53-66. (Article in Journal)

[12] Moeheriono. (2009) Pengukuran Kinerja Berbasis Kompetensi. Bogor : Ghalia Indonesia.

[13] Nurul Rizka Arumsari.2017. Penerapan Planning, Organizing, Actuating, Dan Controlling Di Uptd Dikpora Kecamatan Jepara. Jurnal unpand.ac.id. (Article in Journal)

[14] Powell, WW and Paul J. DiMaggio. 1997. The New Institutionalism in
Organizational Analysis. London: The University of Chicago Press.

[15] Rabiatul Adwiyah. 2015. Kesiapan Sumber Daya Manusia Bidang Pariwisat Indonesia Dalam Menghadapi Mea 2015. ejournal.unisba.ac.id. XII. 1:1-16. (Article in Journal)

[16] Robbins, S. P. 2007. Psikologi Organisasi. Edisi Delapan. Jakarta: Prenhallindo

[17] S.P. Hasibuan, Malayu. 2013. Manajemen Sumber Daya Manusia. Jakarta: PT Bumi Aksara

[18] Sahudiyono. 2015. Memahami FungsiFungsi Manajemen Sumberdaya Manusia (Msdm) Guna Mengoptimalkan Kinerja Perusahaan Pelayaran. Jurnal Bahari Jogja. XIII. 2. (Article in Journal)

[19] Tb. Sjafri Mangkuprawira., Dr.Ir. 2003. Manajemen Sumber Daya Manusia Strategik. Ghalia Indonesia

[20] Tim Dosen Mata Kuliah Manajemen Sumber Daya Manusia Program Studi Teknik Industri. 2009. Buku Ajar Sumber Daya Manusia.

[21] Udin abay. E Learning Solusi Peningkatan Kompetensi SDM Pertanian di Tengah Wabah Covid-19. https://www.swadayaonline.com. 2020.

[22] Ulfah. Sertifikasi Kompetensi BNSP Sama Pentingnya Seperti Ijazah Pendidikan. https://www.indonesiana.id. 2020

[23] Undang-Undang Nomor 10 Tahun 2009 tentang Kepariwisataan

[24] Vika Luila dan Bambang Haryadi. 2013. Pengembangan Fungsi Manajemen Sumber Daya Manusia Pada Pt Ageless Aesthetic Clinic. Jurnal AGORA. 1. 3. (Article in Journal)

[25] Warschauer, M. 2001. Online communication. In R. Carter \& D. Nunan (Eds.), The Cambridge guide to teaching English to speakers of other languages (pp. 207-212). Cambridge: Cambridge University Press. (online). Available: http://www.skillsyouneed.com 